\section{"Howdy Partner"}

\author{
Marvin L. Birnbaum, MD, PhD
}

Our success bas really been based on partnerships from the very beginning.

Bill Gates

In this new wave of technology, you can't do it all yourself, you bave to form alliances.

Carlos Slim Helu

The political tradition of ancient thought, filtered in Italy by Machiavelli, says one thing clearly: every prince needs allies, and the bigger the responsibility, the more allies be needs.

Silvio Berlusconi

"Howdy partner" is an expression from the old cowboy movies. The term partner has assumed a new degree of relevance in the preparation for and responses to emergencies and crises. It has become clear that no organization, regardless of its size, its connections, and/or its authority, is able to impact emergency and disaster preparedness in isolation from other stakeholders involved in similar efforts. This has been highlighted in the soon-to-be published Volume 2 of the Health Disaster Management: Guidelines for Evaluation and Research in the Utstein Style, ${ }^{1}$ and has been mandated by the development of the Clusters in the reorganization of the United Nations, ${ }^{2}$ by the International Strategy for Disaster Reduction (ISDR), ${ }^{3}$ and by the Hyogo Framework. ${ }^{4}$ The Guidelines arbitrarily categorize the functions of a society into one of 13 Basic Societal Functions (BSFs) recognizing that many of the BSFs (often called sectors) are dependent and interdependent on one another. Unfortunately, past experiences demonstrate that many sectors do their important work in isolation from the other sectors. This has been as true for the health sector (medical care and public health) as sectors responsible for BSFs.

A partner can be defined as "a player on the same side or team as another; a person associated with another or others as a principal or a contributor of capital in a business or in a joint venture;" with another or others, esp., in a business firm with shared risks and profits". ${ }^{6}$ A venture is an "undertaking, esp. a business enterprise, involving risk or uncertainty; to do or go despite the risk or uncertainty involved"; ${ }^{8}$ an undertaking of a risk" ${ }^{7}$ A partnership is the state of being a partner or partners. ${ }^{8}$

Disaster and emergency health is multidisciplinary and its performance is profoundly dependent upon most of the other BSFs, as well as the non-governmental and intergovernmental organizations (NGOs, IGOs) and other stakeholders that comprise the private sector. For example, the delivery of medical care is dependent upon transportation, energy, food, potable water, public works, security, vendors of equipment and supplies. In times of crisis, few, if any, medical facilities can remain self-sufficient for more than a few days. Yet, stakeholders have attempted to work independently. Such parochialism not only is inefficient, but often is counter-productive. All of the coordination between BSFs must rest within the Coordination and Control structures of the stricken population or the population at-risk. But, it must be recognized that Coordination and Control structures generally do not own much of what is needed in times of crisis. Therefore, they must interact with a host of administrative structures associated with each of the BSFs and stakeholders in order to obtain the essential personnel, equipment, and supplies required to meet the needs of the stricken population.

These processes require not only cooperation and coordination among all of the stakeholders, but also require collaboration. Collaboration incorporates cooperation and coordination, meaning that resources are shared between the stakeholders. This is the essence of partnerships. Partnerships require a high degree of trust between the partners. The development of trust between stakeholders often is not an easy task and requires efforts, negotiations, and trust between the partners and often actual demonstrations of trust during actual operations.

Every intervention employed in enhancing preparedness for, response to, and recovery from a crisis must have explicit, mutually agreed upon objectives. One risk associated with any intervention is that its objectives may not be met. Defining these objectives is an essential element of any intervention, and requires mutual agreement between all of the stakeholders potentially impacted by the intervention. The stakeholders have valuable concerns to bring to the table. They must be co-opted from a stakeholder position to a partner relationship (partnership). Then, we share the benefits and the risks.

Of particular importance to the World Association for Disaster and Emergency Medicine (WADEM) is the development of partnerships with the private sector. The WADEM can provide the partners with: (1) knowledge, science, and expertise; (2) consultation for development of policies and/or products; (3) focus groups of experts; (4) onthe-ground experience; (5) standards and guidelines; and (6) identification of implications of these developments and/or policies on health. On the other hand, partners can provide the WADEM with: (1) organizational expertise far above that with which we can muster; (2) practical advice; 
(3) identification of the implications of actions in specific areas of expertise; and (4) potential access to needed resources.

Furthermore, partnerships must be forged between other professional organizations including, but not limited to, those of: (1) dentists; (2) engineers; (3) health administrators; (4) nurses; (5) veterinarians; (6) and representatives of each of the sectors responsible for the BSFs. Collaborative agreements must be initiated between the NGOs, IGOs, governmental organizations, businesses, and the academic community. Representatives of these stakeholders must assume a role in the governance of the WADEM. A mechanism for achieving such partnerships initially was proposed by the late Michael Moles and will be discussed during the 15th World Congress on Disaster and Emergency Medicine (15WCDEM) 13-16 May in Amsterdam.

It is important to understand that forging partnerships does not result in sacrificing autonomy, but rather, serves to enrich the experience and the effectiveness of the partners in reaching their common goals. Forging partnerships requires initiatives. I invite the WADEM members, governing bodies, and represented industries to take the initiative to discover opportunities for facilitating important partnerships during the 15WCDEM. Together, we can make a greater impact than by trying to do it alone. We must move upward from the parochialism that exists today. Participate with the WADEM in extending its hand; extend your hand and you may be surprised who will shake it, and as you shake hands, remember to say, "Howdy partner". Enjoy and participate in the 15WCDEM.

If we are together notbing is impossible. If we are divided, all will fail.

Winston Churchill

I bave found no greater satisfaction than achieving success through bonest dealing and strict adberence to the view that, for you to gain, those you deal with should gain as well.

Alan Greenspan

\section{References}

1. Task Force for Quality Control of Disaster Management: Guidelines for Evaluation and Research in the Utstein Style. Madison:World Association for Disaster and Emergency Medicine. 2003.

2. Action Aid International: The Evolving UN Cluster Approach in the Aftermath of the Pakistan Earthquake: An NGO Perspective. Available at http://www.actionaid.org/docs/un_cluster_approach.pdf. Accessed 15 March 2007.
3. International Strategy for Disaster Reduction (ISDR): Hyogo Framework for Action 2005-2015: Building Resilient Nations and Communities to Disasters. Available at: www.unisdr.org/wedr. Accessed 15 March 2007.

4. Idem.

5. The Random House Dictionary, Concise Edition, 1980. Random House, Inc., New York, p 654

6. Thompson D (ed): The Concise Oxford Dictionary of Current English, 9th ed. Clarendon Press: Oxford, 1995.p 996.

7. Ibid. $\mathrm{p} 982$.

8. Ibid.p 1555 . 